\title{
HASIL PADI HIBRIDA GENOTIPE T1683 PADA BERBAGAI DOSIS PUPUK NPK
}

Agastya Putra Pradipta'), Ahmad Yunus ${ }^{2)}$, Samanhudi ${ }^{2)}$

1. Undergraduate Student of Study Program of Agrotechnology, Faculty of Agriculture, University of Sebelas Maret (UNS) in Surakarta

2. Lecturer staff of Study Program of Agrotechnology, Faculty of Agriculture, University of Sebelas Maret (UNS) in Surakarta

Kontak Penulis: agasputraaa@gmail.com

\section{ABSTRACT}

Hybrid rice has genetic traits such as sturdy stems, long and bushy dwarfs, short lifespan of 110-145 days, has large number of tillers, and leaves are dark green. Productivity of hybrid rice reached 6-12 tons ${ }^{-1}$ ha. To obtain maximum production, hybrid rice varieties should be planted on fertile land, nutrients must be available, adequate irrigation, integrated pest management, and crop management should be done well. Efforts that can be done is to provide a balanced fertilizer, one with the use of appropriate doses of NPK fertilizer. The research was conducted in Gedangan Village, Grogol District, Sukoharjo Regency in May to August 2017 using Randomized Complete Block Design (RCBD) design with 2 factors of treatment, is the dosage of NPK fertilizer and rice varieties and replicates 4 times. The results showed that the treatment of various doses of NPK fertilizers and rice varieties increased the results of all observation variables, except in the variable of plant height and yield per harvest. While the interaction between the two treatments almost increased the results of all observation variables except for plant height and yield per harvest.

Keywords: productivity, potential, production

\section{AGROTECHNOLOGY RESEARCH JOURNAL}

Pradipta Putra A, Yunus A, Samanhudi 2017. Hasil padi hibrida genotipe T1683 pada berbagai dosis pupuk NPK. Agrotech Res J 1(2): 24-28.

Pradipta Putra A, Yunus A, Samanhudi 2017. Products of hybrid rice genotype T1683 at various doses of NPK Fertilizer. Agrotech Res J 1(2): 24-28.

\section{PENDAHULUAN}

Kebutuhan pangan nasional kedepan semakin meningkat sejalan dengan bertambahnya jumlah penduduk. Dipihak lain laju peningkatan produksi semakin menurun disebabkan beberapa faktor seperti tidak efisiennya penggunaan pupuk anorganik, terjadinya degradasi lahan, adanya cekaman lingkungan seperti kekeringan, kebanjiran, dan gangguan OPT (tikus, penggerek batang, hama wereng, dan penyakit (kerdil hampa, kerdil rumput, tungro, dll). Permasalahan tersebut semakin berat dengan berkurangnya lahan sawah irigasi akibat alih fungsi lahan dari lahan pertanian menjadi perumahan dan industri (Putra 2012).

Varietas hibrida merupakan teknologi alternatif dalam upaya meningkatkan produksi padi, yaitu dengan memanfaatkan gejala heterosis yang mampu meningkatkan potensi hasil sebesar 15-20\%. China adalah negara pertama di dunia yang menggunakan padi hibrida secara komersial sejak tahun 1976 dan di negara tersebut luas areal pertanaman padi hibrida meningkat hingga mencapai 17 juta ha dengan ratarata hasil panen 6-7 ton/ha. Varietas unggul tidak akan memperlihatkan keunggulannya tanpa didukung oleh teknik budidaya yang optimal. Salah satunya melalui pemupukan. Penggunaan pupuk yang tepat dapat mendukung pertumbuhan tanaman dan dapat menjaga keseimbangan lingkungan.
Berdasarkan hal tersebut, maka penelitian ini dilakukan dengan tujuan untuk mengkaji pengaruh berbagai dosis pupuk NPK terhadap hasil padi hibrida genotipe T1683, menjelaskan perbandingan hasil padi hibrida genotipe T1683 dengan padi inbrida Ciherang, dan mengkaji interaksi antara macam varietas dengan berbagai dosis pupuk NPK.

\section{METODE PENELITIAN}

Penelitian ini dilaksanakan di Lahan Pertanian yang bertempat di Desa Gedangan, Kecamatan Grogol, Kabupaten Sukoharjo pada bulan Mei sampai Agustus 2016. Bahan yang digunakan dalam penelitian adalah benih padi hibrida genotipe T1683, benih padi inbrida ciherang, ladu, herbisida, pestisida, pupuk kandang sapi, pupuk NPK, dan barrier keong. Alat yang digunakan dalam penelitian adalah traktor, cangkul, garu, sorok, tray, patok, meteran jahit, nampan, ember kecil, kamera, gunting, kertas,timbangan analitik, oven, staples, plastik dan alat tulis. Rancangan penelitian yang digunakan adalah Rancangan Acak Kelompok Lengkap (RAKL) dengan 2 faktor yaitu macam dosis pupuk NPK dan macam varietas padi, serta dengan ulangan sebanyak 4 kali, sehingga kan diperoleh 24 kombinasi perlakuan.

Tata laksana penelitian yang dilakukan antara lain budidaya tanaman padi yang meliputi persiapan benih, perispan lahan, persemaian, penanaman, penentuan sampel, pemupukan nda pemberian perlakuan, pengendalian organisme penganggu tanaman, dan pemanenan yang dilakukan saat tanaman mencapai 
95\% gabah telah menguning. Data yang diperoleh dianalisis dengan uji F. Jika pengaruh perlakukan terhadap variabel yang diamati menunjukkan pengaruh yang nyata dapat dilanjutkan dengan uji Duncan pada taraf $5 \%$.

\section{HASIL DAN PEMBAHASAN}

\section{Kondisi umum penelitian}

Penelitian dilaksanakan di lahan sawah Desa Gedangan yang merupakan salah satu desa di wilayah Kecamatan Grogol, Kebupaten Sukoharjo. Lokasi penanaman di Desa Gedangan ini memiliki luasan \pm 174.6740 Ha. Desa Gedangan mempunyai batas wilayah sebelah utara adalah Desa Madegondo dan Desa Kwarasan, sebelah barat adalah Desa Manang dan Desa Kadilangu, sebelah selatan adalah Desa Langenharjo dan Desa Kudu dan sebelah Timur adalah Desa Madegondo dan Desa Langenharjo.

\section{Tinggi tanaman}

Berdasarkan hasil analisis ragam dapat diketahui bahwa perlakuan varietas berpengaruh nyata terhadap tinggi tanaman. Padi hibrida galur T1683 menunjukkan perbedaan tinggi signifikan $118,51 \mathrm{~cm}$ sedangkan padi inbrida Ciherang 97,71 cm (Tabel 1). Menurut Sikuku et al. (2015) yang menyatakan bahwa perbedaan tinggi tanaman disebabkan oleh perbedaan karakteristik dan sifat genetik dari setiap varietas. Perlakuan macam varietas, berdasarkan hasil analisis ragam menunjukkan pengaruh sangat nyata terhadap tinggi tanaman padi. Pernyataan ini didukung oleh Ranawake (2014) yang menyatakan bahwa meskipun sebagian besar karakteristik agronomi tanaman padi dikendalikan oleh faktor lingkungan, namun tinggi tanaman mendapat pengaruh paling sedikit dari faktor lingkungan. Hal ini di dukung oleh Alavan (2015), Varietas unggul tidak akan memperlihatkan keunggulannya tanpa di dukung oleh teknik budidaya yang optimal. Salah satunya adalah pemupukan. Penggunaan pupuk yang tepat dapat mendukung pertumbuhan tanaman dan dapat menjaga keseimbangan lingkungan.

Tabel 1 Pengaruh varietas terhadap tinggi tanaman.

\begin{tabular}{lr}
\hline Varietas & Tinggi tanaman $(\mathrm{Cm})$ \\
\hline Genotipe T1683 & $118,51 \mathrm{a}$ \\
Ciherang & $97,71 \mathrm{~b}$ \\
\hline
\end{tabular}

Keterangan: Angka yang diikuti huruf yang sama menunjukkan tidak beda nyata pada uji Duncan taraf $5 \%$

Berdasarkan hasil analisis ragam dapat diketahui bahwa perlakuan dosis pupuk NPK berpengaruh nyata terhadap tinggi tanaman. Penggunaan dosis pupuk 600 $\mathrm{kg} / \mathrm{ha}$ yang mendapatkan rata-rata tinggi $110,13 \mathrm{~cm}$ (Tabel 2). Menurut Kaya (2013) bahwa pemberian pupuk NPK dapat mempengaruhi tinggi tanaman padi berhubungan dengan meningkatnya ketersediaan nitrogen dalam tanah dan serapan nitrogen oleh tanaman. Hal ini di dukung oleh Putra (2012) yang menyatakan bahwa pemberian pupuk baik itu jenis atau takaran pemupukan sangat mempengaruhi respon tanaman padi sehingga berdampak terhadap pertumbuhan padi khususnya tinggi tanaman. Sependapat dengan (Prasetya 2014). Semakin meningkat dosis pupuk, maka terjadi kenaikan pertumbuhan tinggi tanaman, hal ini disebabkan bahwa dengan semakin dewasanya tanaman, maka sistim perakaran telah berkembang dengan baik dan lengkap, sehingga tanaman semakin mampu menyerap unsur hara dalam bentuk anion dan kation yang mengandung unsur N, P dan K yang terdapat pada pupuk Mutiara tersebut.

Tabel 2 Pengaruh dosis pupuk NPK terhadap tinggi tanaman

\begin{tabular}{lr}
\hline Dosis Pupuk NPK $\left(\mathrm{Kg}^{-1} \mathrm{Ha}\right)$ & Tinggi tanaman $(\mathrm{Cm})$ \\
\hline 500 & $107,36 \mathrm{a}$ \\
600 & $110,13 \mathrm{~b}$ \\
700 & $106,85 \mathrm{a}$ \\
\hline
\end{tabular}

Keterangan: Angka yang diikuti huruf yang sama menunjukkan tidak beda nyata pada uji Duncan taraf $5 \%$

\section{Jumlah anakan per rumpun}

Hasil analisis ragam menunjukkan bahwa varietas dan macam dosis pupuk NPK berpengaruh nyata terhadap jumlah anakan per rumpun. Perlakuan padi inbrida Ciherang dengan dosis pupuk NPK $600 \mathrm{~kg}^{-1} \mathrm{ha}$ mendapatkan rata-rata terbanyak 22 batang (Tabel 3). Menurut Yurnavira (2015), pupuk NPK dapat meningkatkan pertumbuhan vegetatif tanaman padi (tinggi tanaman dan jumlah anakan per rumpun). Hal ini terjadi karena pupuk kandang dan pupuk NPK dapat menyediakan unsur hara makro dan mikro dalam jumlah yang cukup seimbang bagi pertumbuhan dan perkembangan tanaman. Hal ini diperkuat oleh Yetti (2010), jumlah anakan akan maksimal apabila tanaman memiliki sifat genetik yang baik di tambah dengan keadaan lingkungan yang menguntungkan atau sesuai dengan pertumbuhan dan perkembangan tanaman.

Tabel 3 Pengaruh varietas dan dosis pupuk NPK terhadap jumlah anakan per rumpun.

\begin{tabular}{lccc}
\hline \multirow{2}{*}{ Varietas } & \multicolumn{4}{c}{ Dosis Pupuk NPK $\left(\mathrm{Kg}^{-1} \mathrm{Ha}\right)$} \\
\cline { 2 - 4 } & 500 & 600 & 700 \\
\hline Genotipe T1683 & $19 \mathrm{~b}$ & $15 \mathrm{a}$ & $16 \mathrm{a}$ \\
Ciherang & $20 \mathrm{bc}$ & $22 \mathrm{c}$ & $21 \mathrm{c}$ \\
\hline
\end{tabular}

Keterangan: Angka yang diikuti huruf yang sama menunjukkan tidak beda nyata pada uji Duncan taraf $5 \%$

\section{Panjang malai}

Hasil analisis ragam menunjukkan bahwa varietas dan macam dosis pupuk NPK berpengaruh nyata terhadap panjang malai. Perlakuan padi hibrida galur T1683 dengan dosis pupuk NPK $600 \mathrm{~kg} / \mathrm{ha}$ mendapatkan hasil tertinggi dengan rata-rata panjang 27,42 cm (Tabel 4). Menurut Hatta (2010), panjang malai juga tergantung kepada varietas tanaman itu sendiri, semakin panjang malai berpengaruh terhadap jumlah gabah per malai. Yurnavira (2015) menambahkan, bahwa pemberian pupuk NPK meningkatkan panjang malai tanaman padi, dalam hal ini unsur nitrogen berperan penting pada proses 
pertambahan panjang malai tanaman padi, semakin tinggi nitrogen maka malai juga akan semakin panjang.

Kemampuan tanaman untuk menghasilkan jumlah gabah per malai dipengaruhi oleh berbagai faktor salah satu faktor yang paling penting adalah karakteristik panjang malai dan ketersediaan hara. Setiap varietas memiliki karakteristik panjang malai yang berbeda. Adanya perbedaan panjang malai berpengaruh terhadap perbedaan jumlah bakal gabah dengan kecenderungan semakin panjang malai semakin banyak bakal gabah yang terbentuk (Mahmud 2014).

Tabel 4 Pengaruh varietas dan dosis pupuk NPK terhadap panjang malai.

\begin{tabular}{llll}
\hline \multirow{2}{*}{ Varietas } & \multicolumn{3}{l}{ Dosis Pupuk NPK $\left(\mathrm{Kg}^{-1} \mathrm{Ha}\right)$} \\
\cline { 2 - 4 } & 500 & 600 & 700 \\
\hline Genotipe T1683 & $25,47 \mathrm{c}$ & $27,42 \mathrm{~d}$ & $25,62 \mathrm{c}$ \\
Ciherang & $24,65 \mathrm{~b}$ & $23,67 \mathrm{a}$ & $23,72 \mathrm{a}$ \\
\hline
\end{tabular}

Keterangan: Angka yang diikuti huruf yang sama menunjukkan tidak beda nyata pada uji Duncan taraf $5 \%$

\section{Jumlah malai per rumpun}

Hasil analisis ragam menunjukkan bahwa varietas dan macam dosis pupuk NPK berpengaruh nyata terhadap jumlah malai per rumpun.Perlakuan padi inbrida Ciherang dengan dosis pupuk NPK $600 \mathrm{~kg}^{-1}$ ha mendapatkan jumlah malai terbanyak 25 batang (Tabel 5). Menurut Mawardiana (2013), bahwa pupuk NPK menunjukkan pengaruh nyata terhadap jumlah malai per rumpun. Di dukung oleh pernyataan Mahmud (2014), bahwa perolehan jumlah malai per rumpun berkaitan erat dengan kemampuan tanaman menghasilkan anakan dan kemampuan mempertahankan berbagai fungsi fisiologis tanaman. Semakin banyak anakan yang terbentuk semakin besar peluang terbentuknya anakan yang menghasilkan malai. Sependapat dengan Lita (2013) , bahwa jumlah malai merupakan salah satu indikator produksi tanaman. Jumlah malai yang dihasilkan tanaman akan mempengaruhi bobot gabah kering panen dan produksi malai.

Tabel 5 Pengaruh varietas dan dosis pupuk NPK terhadap jumlah malai per rumpun.

\begin{tabular}{llll}
\hline \multirow{2}{*}{ Varietas } & \multicolumn{3}{l}{ Dosis } \\
\cline { 2 - 4 } & 500 & 600 & 700 \\
\hline Genotipe T1683 & $22 \mathrm{~b}$ & $18 \mathrm{a}$ & $19 \mathrm{a}$ \\
Ciherang & $23 \mathrm{bc}$ & $25 \mathrm{c}$ & $23 \mathrm{bc}$ \\
\hline
\end{tabular}

Keterangan: Angka yang diikuti huruf yang sama menunjukkan tidak beda nyata pada uji Duncan taraf $5 \%$

\section{Persentase gabah bernas per tanaman}

Hasil analisis ragam menunjukkan bahwa varietas dan macam dosis pupuk NPK berpengaruh nyata terhadap persentase gabah bernas per tanaman. Perlakuan padi hibrida T1683 dengan dosis pupuk NPK $600 \mathrm{~kg} / \mathrm{ha}$ mendapatkan rata-rata paling tinggi 68,20\% (Tabel 6). Menurut Patt (2015), bahwa dengan ketersediaan nutrisi yang cukup pada tanaman memacu pertumbuhan akar dan pembentukkan sistem perakaran tanaman yang baik sehingga tanaman dapat mengambil unsur hara lebih banyak. Tersedianya unsur hara yang cukup akan memacu pembentukan bunga dan memperbesar persentase bunga jadi.

Tingginya persentase gabah isi per malai sangat dipengaruhi oleh jumlah gabah per malai dan jaminan hara yang tersedia. Kondisi lingkungan tumbuh yang sesuai cenderung merangsang proses inisiasi malai menjadi sempurna, sehinggapeluang terbentuknya bakal gabah menjadi lebih banyak. Namun demikian semakin banyak gabah yang terbentuk, meningkatkan beban tanaman untuk membentuk gabah bernas. Apabila saat proses pengisian gabah, tidak diimbangi dengan ketersediaan hara yang mencukupi akan banyak terbentuk gabah hampa. Persentase gabah isi merupakan salah satu indikator produktivitas tanaman, semakin tinggi persentase gabah isi yang diperoleh suatu varietas menandakan varietas tersebut mempunyai produktivitas yang tinggi (Mahmud 2014).

Tabel 6 Pengaruh varietas dan dosis pupuk NPK terhadap persentase gabah per tanaman.

\begin{tabular}{llll}
\hline \multirow{2}{*}{ Varietas } & \multicolumn{3}{l}{ Dosis Pupuk NPK $\left(\mathrm{Kg}^{-1} \mathrm{Ha}\right)$} \\
\cline { 2 - 4 } & 500 & 600 & 700 \\
\hline Genotype T1683 & $68,20 \mathrm{~b}$ & $49,00 \mathrm{a}$ & $51,07 \mathrm{a}$ \\
Ciherang & $61,05 \mathrm{~b}$ & $61,02 \mathrm{~b}$ & $67,85 \mathrm{~b}$ \\
\hline
\end{tabular}

Keterangan: Angka yang diikuti huruf yang sama menunjukkan tidak beda nyata pada uji Duncan taraf $5 \%$

\section{Bobot 1000 biji gabah bernas}

Hasil analisis ragam menunjukkan bahwa varietas dan macam dosis pupuk NPK berpengaruh sangat nyata terhadap bobot 1000 biji gabah bernas. Padi hibrida galur T1683 dengan dosis pupuk NPK 500 $\mathrm{kg} / \mathrm{ha}$ mendapatkan hasil rata-rata yang tertinggi 22,86 g (Tabel 7). Menurut Gustiana (2012) hasil biji setiap tanaman selain dipengaruhi oleh genotipe, juga dipengaruhi oleh budidaya dan keadaan lingkungan tumbuh, seperti kandungan unsur hara yang cukup tersedia bagi tanaman. Kandungan unsur hara yang cukup tersedia bagi tanaman merupakan kandungan hara yang dibutuhkan dan dapat diserap oleh tanaman. Hal ini di dukung oleh Kanfany (2014), bahwa umumnya hasil gabah meningkat dengan meningkatnya tingkat pupuk bagi varietas hibrida. Sejalan dengan penelitian Soplanit (2012), bahwa perlakuan NPK berpengaruh nyata terhadap bobot 1000 biji bila dibandingkan tanpa adanya perlakuan pupuk (kontrol).

Tabel 7 Pengaruh varietas dan dosis pupuk NPK terhadap bobot 1000 biji gabah bernas.

\begin{tabular}{llll}
\hline \multirow{2}{*}{ Varietas } & \multicolumn{3}{l}{ Dosis Pupuk NPK $\left(\mathrm{Kg}^{-1} \mathrm{Ha}\right)$} \\
\cline { 2 - 4 } & 500 & 600 & 700 \\
\hline Genotype T1683 & $22,86 \mathrm{c}$ & $19,61 \mathrm{~b}$ & $17,76 \mathrm{a}$ \\
Ciherang & $20,90 \mathrm{~b}$ & $19,80 \mathrm{~b}$ & $20,48 \mathrm{~b}$ \\
\hline
\end{tabular}

Keterangan: Angka yang diikuti huruf yang sama menunjukkan tidak beda nyata pada uji Duncan taraf $5 \%$

\section{Bobot gabah kering per tanaman}

Hasil analisis ragam menunjukkan bahwa varietas dan macam dosis pupuk NPK berpengaruh nyata terhadap bobot gabah kering per tanaman. Perlakuan 
padi hibrida galur T1683 dengan dosis pupuk NPK $500 \mathrm{~kg}^{-1} \mathrm{ha}$ mendapatkan rata-rata tertinggi $37,99 \mathrm{~g}$ (Tabel 8). Tingginya produksi suatu varietas menurut Nazirah (2015) mungkin disebabkan oleh faktor genetik dari kultivar tersebut yang memang mempunyai potensi hasil yang lebih baik. Hal ini juga didukung oleh pernyataan Mahmud (2014) bahwa tinggi rendahnya suatu varietas berhubungan erat dengan komponen hasil seperti jumlah malai per rumpun, jumlah gabah per malai, persentase gabah isi dan bobot 1.000 butir gabah isi.

Tabel 8 Pengaruh varietas dan dosis pupuk NPK terhadap bobot gabah kering per tanaman.

\begin{tabular}{llll}
\hline \multirow{2}{*}{ Varietas } & \multicolumn{3}{l}{ Dosis Pupuk NPK $\left(\mathrm{Kg}^{-1} \mathrm{Ha}\right)$} \\
\cline { 2 - 4 } & 500 & 600 & 700 \\
\hline Genotype T1683 & $37,99 \mathrm{c}$ & $28,91 \mathrm{~b}$ & $22,92 \mathrm{a}$ \\
Ciherang & $34,69 \mathrm{c}$ & $26,39 \mathrm{ab}$ & $28,75 \mathrm{~b}$ \\
\hline
\end{tabular}

Keterangan: Angka yang diikuti huruf yang sama menunjukkan tidak beda nyata pada uji Duncan taraf $5 \%$

\section{Hasil panen per petak}

Hasil analisis ragam menunjukkan bahwa varietas dan macam dosis pupuk NPK berpengaruh nyata terhadap hasil panen per petak. Padi hibrida galur T1683 dengan dosis pupuk NPK $700 \mathrm{~kg} / \mathrm{ha}$ mendapatkan hasil paling tertinggi dari semua perlakuan $9,5 \mathrm{~kg}^{-1} \mathrm{~m} 2$. Sejalan dengan penelitian Kanfany (2014), bahwa umumnya hasil gabah meningkat dengan meningkatnya tingkat pupuk bagi varietas hibrida. Menurut Nazirah (2015), tingginya produksi suatu varietas mungkin disebabkan oleh faktor genetik dari kultivar tersebut yang memang mempunyai potensi hasil yang lebih baik.

\section{KESIMPULAN}

Berdasarkan hasil penelitian yang telah dilakukan, maka dapat disimpulkan :

1. Pada perlakuan padi hibrida galur T1683 dengan dosis pupuk NPK $500 \mathrm{~kg}^{-1}$ ha meningkatkan hasil pada variabel presentase gabah bernas per tanaman, bobot 1000 biji gabah bernas, dan berat gabah kering per tanaman. Pada perlakuan padi hibrida galur T1683 dosis pupuk NPK $600 \mathrm{~kg}^{-1}$ ha meningkatkan hasil pada variabel tinggi tanaman dan panjang malai. Padi inbrida Ciherang dengan dosis pupuk NPK $600 \mathrm{~kg}^{-1}$ ha meningkatkan hasil pada variabel jumlah anakan per rumpun, jumlah anakan produktif dan jumlah malai per rumpun.

2. Hasil produksi padi hibrida China galur T1683 9,5 $\mathrm{kg}^{-1} \mathrm{~m} 2$ atau setara dengan 4,75 ton dan padi inbrida Ciherang $7,6 \mathrm{~kg}^{-1} \mathrm{~m} 2$ atau setara dengan 3,8 ton.

3. Interaksi antara varietas dengan macam dosis pupuk NPK mampu meningkatkan hasil semua variabel pengamatan kecuali tinggi tanaman dan hasil panen per petak.

\section{SARAN}

Berdasarkan penelitian ini, maka perlu adanya :

1. Penelitian lebih lanjut dengan penggunaan variasi dosis pupuk NPK maupun dengan pemupukan lain
2. Budidaya tanaman yang lebih baik mulai dari penanaman secara bersamaan dan perlindungan tanaman yang lebih intensif dari organisme pengganggu tanaman yang dapat merugikan dan menurunkan kualitas dan kuantitas gabah.

\section{DAFTAR PUSTAKA}

Adisarwanto T. 2006. Budidaya kedelai dengan pemupukan yang efektif dan pengoptimalan peran bintil akar. Jakarta: Penebar Swadaya

Alavan A, Hayati R, Hayati E. 2015. Pengaruh pemupukan terhadap pertumbuhan beberapa varietas padi gogo (Oryza sativa L.). J Floratek. 10: 61-68.

Kanfany G, Raafat EK, Kabirou. 2014. Assement of rice inbred lines and hybrids under low fertilizer levels in Senegal. Sustainability 6: 1153-1162.

Kaya E. 2013. Pengaruh kompos jerami dan pupuk NPK terhadap $\mathrm{N}$-tersedia tanah, serapan- $\mathrm{N}$, pertumbuhan, dan hasil padi sawah (Oryza sativa L.). Prosiding FMIPA Universitas Pattimura.

Lita TN. 2013. Pengaruh perbedaan system tanam terhadap pertumbuhan dan hasil tanaman padi (Oryza sativa L.) di lahan sawah. J Produksi Tanaman. 1(4): 361-368.

Mahmud Y, Purnomo SS. 2014. Keragaman agronomis beberapa varietas unggul baru tanaman padi (Oryza sativa L.) pada model pengelolaan tanaman terpadu. J Ilmiah Solusi. 1(1): 1-10.

Mawardiana, Sufardi, Edi H. 2013. Pengaruh residu biochar dan pemupukan NPK terhadap dinamika nitrogen, sifat kimia tanah dan hasil tanaman padi (Oryza sativa L.) musim tanam ketiga. J Manajemen Sumber Daya Lahan. 2(3): 255-260.

Nazirah L, B Sengli, J Damanik. 2015. Pertumbuhan dan hasil tiga varietas padi gogo pada perlakuan pemupukan. J Floratek. 10: 54-60.

Paat A. 2015. Respons pertumbuhan dan produksi padi sawah metode SRI (System of Rice Intensification) terhadap pemberian pupuk organik dan anorganik. Fakultas Pertanian Universitas Samratulangi.

Prasetya ME. 2014. Pengaruh pupuk NPK mutiara dan pupuk kandang sapi terhadap pertumbuhan dan hasil tanaman cabai merah keriting varietas arimbi (Capsicum annuum L.). J Agrifor. 8(2): 191-198.

Putra S. 2012. Pengaruh pupuk NPK tunggal, majemuk, dan pupuk daun terhadap peningkatan produksi padi gogo varietas situ patenggang. Agrotrop 2(1): 55-61.

Sikuku PA, Kimani JM, Kamau JW, Njinju S. 2015. Evaluation of different improved upland rice varieties for low soil nitrogen adaptability. Int $\mathrm{J}$ of Plant and Soil Science. 5(1): 40-49.

Soplanit R, SH Nukuhaly. 2012. Pengaruh pengelolaan hara NPK terhadap ketersediaan $\mathrm{n}$ dan hasil tanaman padi sawah (Oryza sativa L.) di desa waelo kecamatan waeapo kabupaten buru. Agrologia 1(1):81-90.

Yetti H, Ardian. 2010. Pengaruh penggunaan jarak tanam terhadap pertumbuhan dan produksi padi sawah (Oryza sativa L.) varietas IR 42 dengan metode SRI (System Of Rice Intensification). SAGU $9(1): 21-27$. 
Yurnavira I. 2015. Pengaruh jenis pupuk organic dan dosis pupuk NPK terhadap pertumbuhan dan hasil padi (Oryza sativa L.) sawah pada sistem konvensional. Fakultas Pertanian Universitas Tamansiswa Padang. 